\title{
SILICATE FERTILIZATION OF TROPICAL SOILS: SILICON AVAILABILITY AND RECOVERY INDEX OF SUGARCANE ${ }^{(1)}$
}

\author{
Mônica Sartori de Camargo ${ }^{(2)}$, Gabriela Rocha ${ }^{(3)}$ \& Gaspar Henrique Korndörfer ${ }^{(4)}$
}

\begin{abstract}
SUMMARY
Sugarcane is considered a Si-accumulating plant, but in Brazil, where several soil types are used for cultivation, there is little information about silicon (Si) fertilization. The objectives of this study were to evaluate the silicon availability, uptake and recovery index of Si from the applied silicate on tropical soils with and without silicate fertilization, in three crops. The experiments in pots $(100 \mathrm{~L})$ were performed with specific $\mathrm{Si}$ rates $\left(0,185,370\right.$ and $555 \mathrm{~kg} \mathrm{ha}^{-1}$ $\mathrm{Si}$ ), three soils (Quartzipsamment-Q, 6 \% clay; Rhodic Hapludox-RH, $22 \%$ clay; and Rhodic Acrudox-RA, 68 \% clay), with four replications. The silicon source was $\mathrm{Ca}-\mathrm{Mg}$ silicate. The same $\mathrm{Ca}$ and $\mathrm{Mg}$ quantities were applied to all pots, with lime and/or $\mathrm{MgCl}_{2}$, when necessary. Sugarcane was harvested in the plant cane and first- and second-ratoon crops. The silicon rates increased soil $\mathrm{Si}$ availability and $\mathrm{Si}$ uptake by sugarcane and had a strong residual effect. The contents of soluble $\mathrm{Si}$ were reduced by harvesting and increased with silicate application in the following decreasing order: $Q>R H>R A$. The silicate rates promoted an increase in soluble $\mathrm{Si}$-acetic acid at harvest for all crops and in all soils, except $\mathrm{RA}$. The amounts of $\mathrm{Si}-\mathrm{CaCl}_{2}$ were not influenced by silicate in the ratoon crops. The plant $\mathrm{Si}$ uptake increased according to the $\mathrm{Si}$ rates and was highest in RA at all harvests. The recovery index of applied $\mathrm{Si}$ (RI) of sugarcane increased over time, and was highest in RA.

Index terms: cultivar, nutrition, fertilization, monocotyledons.
\end{abstract}

(1) Received for publication on June 19, 2012 and approved on July 11, 2013.

(2) Scientific researcher at the Agência Paulista de Tecnologia dos Agronegócios - APTA/Pólo Centro Sul. Rodovia SP $127, \mathrm{~km} 30$. P.O. Box 28. CEP 13412-050 Piracicaba (SP), Brazil. E-mail: mscamarg@yahoo.com.br

(3) Undergraduate student in Biofuel Technologies at the Faculdade de Tecnologia. R. Diácono Jair de Oliveira, s/n. CEP 13414155 Piracicaba (SP), Brazil. Scientific initiation scholarship of the FAPESP. E-mail: gabriela_rocha@hotmail.com

(4) Full Professor at the Instituto de Ciências Agrárias, Universidade Federal de Uberlândia - UFU. P.O. Box 953. CEP 38400-902 Uberlândia (MG), Brazil. Scholarship of CNPq. E-mail: ghk@uber.com.br 


\title{
RESUMO: ADUBAÇÃO SILICATADA EMSOLOS TROPICAIS:DISPONIBILIDADE DE SILÍCIO E SUA RECUPERAÇÃO PELA CANA-DE-AÇÚCAR
}

\begin{abstract}
A cana-de-açúcar é considerada acumuladora de silício (Si). Há poucas informações sobre a adubação silicatada no Brasil, onde vários tipos de solos têm sido utilizados no seu cultivo. $O$ objetivo deste estudo foi avaliar a disponibilidade, absorção de Si e índice de recuperação de Si do silicato em três cortes de cana-de-açúcar cultivada em solos tropicais com e sem aplicação de silicato. Os experimentos foram conduzidos em vasos de $100 \mathrm{~L}$ com quatro doses de Si (0, 185, 370 e $555 \mathrm{~kg} \mathrm{ha}^{-1}$ ) em três solos (Neossolo Quartzarênico - RQ, 6 \% argila; Latossolo Vermelho - LV, $22 \%$ argila; e Latossolo Vermelho distroférrico - LVdf, $68 \%$ argila) e quatro repetições. A fonte de Si foi silicato de cálcio e magnésio. Todas as parcelas receberam as mesmas quantidades de Ca e $\mathrm{Mg}$ com adições de calcário e, ou, $\mathrm{MgCl}_{2}$, quando foram necessárias. A colheita da parte aérea foi feita na cana-planta, na primeira e segunda soca. As doses de silício aumentaram sua disponibilidade e absorção com forte efeito residual. Houve redução dos teores de Si solúvel com os cortes e o RQ apresentou o maior incremento com a adubação silicatada, seguidos do LV e LVdf. As doses de Si elevaram o teor de Si solúvel em ácido acético nos solos para os três cortes, exceto para LVdf. A adubação silicatada não influenciou os teores de Si em $\mathrm{CaCl}_{2}$ nas soqueiras. A absorção de Si foi intensificada com as doses de Si aplicadas, sendo mais altas no LVdf em todos os cortes. A recuperação de Si proveniente do silicato aumentou com o tempo e o LVdf apresentou maiores valores.
\end{abstract}

Termos de indexação: cultivar, nutrição, fertilização, monocotiledôneas.

\section{INTRODUCTION}

Sugarcane is one of the most important crops for the Brazilian economy, with a return of about US\$ 11 billion in 2008 from the sale of sugar and ethanol (CONAB, 2012). Brazil is a major worldwide producer of sugarcane, with an output of approximately 605 million tons in the $2009 / 10$ growing season (CONAB, 2012). In 2008, about 1.3 million jobs were related to this crop. Particularly in the rural areas of São Paulo State, where sugarcane is grown on a large area and has a high yield, employment is also generated (CONAB, 2012). Moreover, the crop represents a positive response to environmental concerns because sugarcane can be used to produce ethanol, which is a source of clean and renewable energy.

Sugarcane is being grown on several soil types in Brazil. Today, areas for a potential expansion of sugarcane are located in regions with highly weathered soils, characterized by low soluble silicon (Si) contents. Although $\mathrm{Si}$ is not an essential element, the yields of Si-accumulating plants such as sugarcane could be reduced by the typically intensive management and monoculture used in these types of soils in humid tropical areas (Korndörfer et al., 2002a).

There is little information about $\mathrm{Si}$ availability to sugarcane in Brazilian soils, but results of silicon fertilization have been positive in soils (Korndörfer et al., 2002b) containing less than 6 to $8 \mathrm{mg} \mathrm{kg}^{-1} \mathrm{Si}$ (extracted with $0.01 \mathrm{~mol} \mathrm{~L}^{-1} \mathrm{CaCl}_{2}$ ). In Australia, studies on Si fertilization of sugarcane (Berthelsen et al., 1998, 2001) provided information for soil classification with regard to $\mathrm{Si}$ availability, as proposed by Berthelsen et al. (2002). These authors classified the soils into four groups, based on the level of soluble
Si extracted with $\mathrm{CaCl}_{2}\left(0.01 \mathrm{~mol} \mathrm{~L}^{-1}\right)$ : very low (0-5 mg kg-1), low (5-10 $\left.\mathrm{mg} \mathrm{kg}^{-1}\right)$, limited (10-20 $\left.\mathrm{mg} \mathrm{kg}^{-1}\right)$, and sufficient ( 20 to $>50 \mathrm{mg} \mathrm{kg}^{-1}$ ).

Silicate fertilization of sugarcane has been used to good effect in many countries, such as the United States, Australia, and South Africa (Ayres, 1966; Fox et al., 1967; Ross et al., 1974; Elawad et al., 1982; Berthelsen et al., 1999). In Brazil, the application of $4 \mathrm{t} \mathrm{ha}^{-1}$ of sodium metasilicate resulted in an increase of $14 \mathrm{t} \mathrm{ha}^{-1}$ in the yield of sugarcane grown on a Quartzipsamment soil (Korndörfer et al., 2002b). According to Silveira et al. (2003), the addition of silicate promoted an increase of $11 \mathrm{t} \mathrm{ha}^{-1}$ in the sugarcane yield of plant cane grown on a Rhodic Hapludox (sandy clay loam). Brassioli et al. (2009) showed that silicate application provided the highest yield increase, more than lime in the third, fourth and fifth ratoon crops. However, only few studies have evaluated Si uptake at harvest or the recovery index of Si from the applied silicate (Khalid et al., 1978; Sousa et al., 2010), which is important to improve the sugarcane management in terms of Si fertilization.

Considering the lack of data regarding silicon fertilization of sugarcane, especially in ratoon crops, the objectives of this study were to evaluate silicon availability, uptake and recovery index of Si from the applied silicate in three sugarcane crops in tropical soils, with and without silicate fertilization.

\section{MATERIALS AND METHODS}

The experiments were performed with sugarcane grown in pots $(100 \mathrm{~L})$ under field conditions in Piracicaba (22 42” $30^{\prime}$ S; $47^{\circ} 38^{\prime \prime} 01^{\prime}$ W), State of São 
Paulo, Brazil, between January 2008 and October 2010. The sugarcane cultivar IAC 873396 was selected due to its robust growth in many different soil types (Landell et al., 1997).

The experiments were arranged in a completely randomized factorial design $(4 \times 3)$ with four silicon rates $\left(0,185,370\right.$ and $\left.555 \mathrm{~kg} \mathrm{ha}^{-1} \mathrm{Si}\right)$ and three soils, Quartzipsamment (Q; 6 \% clay), Rhodic Hapludox (RH; $22 \%$ clay) and a Rhodic Acrudox (RA; $68 \%$ clay), in four replications. The soils were chemically analyzed as described by Raij et al. (1997), and the total contents of $\mathrm{SiO}_{2}, \mathrm{Fe}_{2} \mathrm{O}_{3}$ and $\mathrm{Al}_{2} \mathrm{O}_{3}$ (Table 1) were determined as proposed by Vettori (1969). The silicon sources were calcium and magnesium silicate, containing total amounts of: $10.8 \mathrm{~g} \mathrm{~kg}^{-1} \mathrm{Si}, 262 \mathrm{~g} \mathrm{~kg}^{-1}$ $\mathrm{Ca}$, and $56.8 \mathrm{~g} \mathrm{~kg}^{-1} \mathrm{Mg}$. To ensure the same Ca and $\mathrm{Mg}$ quantities in all pots, lime $\left(343 \mathrm{~g} \mathrm{~kg}^{-1} \mathrm{Ca}, 96 \mathrm{~g} \mathrm{~kg}^{-1}\right.$ $\mathrm{Mg})$ and $/ \mathrm{or} \mathrm{MgCl}_{2}(11.9 \% \mathrm{Mg})$ were also used in some treatments (Table 2).

Soil under native vegetation was sampled, air-dried and sieved through a 5-mm screen before being filled in $100 \mathrm{~L}$ pots. The pots were drilled and filled with crushed stone $(10 \mathrm{~L})$, which was covered with a layer of bidim geosynthetics to facilitate water drainage. Each pot was filled with 80, 96 and $112 \mathrm{~kg}$ of RA, $\mathrm{RH}$ and $\mathrm{Q}$ soils, respectively, equivalent to $80 \mathrm{~L}$. The treatments (silicate, lime and/or $\mathrm{MgCl}_{2}$ ) were applied to the upper $20 \mathrm{~cm}$ of the soil. These treatments were applied on December 02, 2007, and the pots incubated for six weeks to allow for soil chemical reactions before seedling transplantation. During this period, sugarcane seedlings were produced from single-budded setts cut from stalks from a commercial field.

Table 1. Chemical characteristics of the Quartzipsamment (Q), Rhodic Hapludox (RH) and Rhodic Acrudox (RA) soils used in the experiments

\begin{tabular}{lrrr}
\hline Characteristic & Q & RH & RA \\
\hline Organic matter $^{(1)}\left(\mathrm{g} \mathrm{dm}^{-3}\right)$ & 11.0 & 22.0 & 26.0 \\
$\mathrm{pH}\left(\mathrm{CaCl}_{2} 0.01 \mathrm{~mol} \mathrm{~L}^{-1}\right)$ & 4.2 & 4.6 & 4.0 \\
$\mathrm{P}^{(2)}\left(\mathrm{mg} \mathrm{dm}^{-3}\right)$ & 3.0 & 8.0 & 18.0 \\
$\mathrm{~K}^{(3)}\left(\mathrm{mmol}_{\mathrm{c}} \mathrm{dm}^{-3}\right)$ & 0.4 & 0.7 & 0.9 \\
$\mathrm{Ca}^{(3)}\left(\mathrm{mmol}_{\mathrm{c}} \mathrm{dm}^{-3}\right)$ & 3.0 & 18.0 & 7.0 \\
$\mathrm{Mg}^{(3)}\left(\mathrm{mmol}_{\mathrm{c}} \mathrm{dm}^{-3}\right)$ & 1.0 & 5.0 & 3.0 \\
$\mathrm{CEC}\left(\mathrm{mmol}_{\mathrm{c}} \mathrm{dm}^{-3}\right)$ & 20.4 & 54.7 & 90.9 \\
$\mathrm{Base} \mathrm{Saturation}(\mathrm{BS} \%)$ & 21.6 & 44.6 & 30.8 \\
$\mathrm{Aluminum} \mathrm{saturation}(\mathrm{m} \%)$ & 41.0 & 8.0 & 62.0 \\
$\mathrm{Si}-{\text { acetic acid }\left(\mathrm{mg} \mathrm{kg}^{-1}\right)}_{\mathrm{Si}-\mathrm{CaCl}_{2}\left(\mathrm{mg} \mathrm{kg}^{-1}\right)}^{1.0}$ & 8.1 & 10.7 \\
$\mathrm{SiO}_{2}(\%)$ & 0.9 & 4.9 & 5.7 \\
$\mathrm{Al}_{2} \mathrm{O}_{3}(\%)$ & 0.9 & 4.1 & 18.6 \\
$\mathrm{Fe}_{2} \mathrm{O}_{3}(\%)$ & 1.9 & 6.5 & 19.7 \\
\hline
\end{tabular}

(1) Walkley \& Black method; (2) Extracted by anion-exchange resin; ${ }^{(3)}$ Ammonium acetate; ${ }^{(4)} \mathrm{H}_{2} \mathrm{SO}_{4}$ method (Vettori, 1969).
On January 14, 2008, macronutrients (180 kg ha-1 $\mathrm{P}_{2} \mathrm{O}_{5}, 30 \mathrm{~kg} \mathrm{ha}^{-1} \mathrm{~N}$, and $100 \mathrm{~kg} \mathrm{ha}^{-1} \mathrm{~K}_{2} \mathrm{O}$ ) were mixed with the upper $20 \mathrm{~cm}$ of soil, and two sugarcane plantlets with heights between 10 and $15 \mathrm{~cm}$ were planted in each pot $(100 \mathrm{~L})$. The surface fertilization $\left(30 \mathrm{~kg} \mathrm{ha}^{-1} \mathrm{~N}, 100 \mathrm{~kg} \mathrm{ha}^{-1} \mathrm{~K}_{2} \mathrm{O}\right)$ took place 30 days after planting. Micronutrients were not used because the levels in the soil were considered sufficient, according to Raij et al. (1997). After plant cane harvest, $\mathrm{N}$ and K were applied to the soil surface during the first and second ratoon crops, according to Raij et al. (1997).

The plant cane was harvested on November 26, 2008; the first ratoon on October 27, 2009; and the second ratoon crop on October 4, 2010. The aerial parts of the plants were dried, weighed, and ground. The silicon contents in the dry matter tissue of the aerial parts of the plant cane were determined according to Elliot \& Snyder (1991). The silicon uptake was determined by multiplying the Si content by the dry matter weight.

Six soil samples per pot were collected after each harvest for chemical analyses (Raij et al., 1997). The Si soil content was evaluated by two extraction media: $0.05 \mathrm{~mol} \mathrm{~L}^{-1}$ acetic acid and $0.01 \mathrm{~mol} \mathrm{~L}^{-1} \mathrm{CaCl}_{2}$ (Korndörfer et al., 1999).

The Si uptake by sugarcane from silicate (SiFF) was calculated using the following equation: $\mathrm{SiFF}=$ Si uptake - Si uptake by the control (Khalid et al., 1978; Souza et al., 2010). The percentage of the recovery index of $\mathrm{Si}(\mathrm{RI})$ in the three soils with $\mathrm{Si}$ application was also calculated using RI $(\%)=(\mathrm{Si}$ uptake by sugarcane from silicate/Si applied)*100.

Analyses of variance of the data were carried out, applying the $\mathrm{F}$ test. The data means were tested using the Tukey test, and regression models were used to analyze the effects of $\mathrm{Si}$ application rates with the Statistical Analysis System software (SAS®, USA).

\section{RESULTS AND DISCUSSION}

The $\mathrm{pH}$ values, the contents of phosphorus $(\mathrm{P})$, calcium $(\mathrm{Ca})$, potassium $(\mathrm{K})$, and magnesium $(\mathrm{Mg})$, and the percent base saturation (BS) were sufficient, according to Raij et al. (1997), to ensure a good sugarcane development during the experiments (Tables 3 and 4). The nutrient levels (data not shown) of the diagnostic leaves collected from the top-visibledewlap for the evaluation of the nutritional status were all within the range considered sufficient by Raij et al. (1997). On the contrary, the K contents were insufficient after the harvest of all three crops due to an increased nutrient uptake in the pre-harvest stage (data not shown).

Nutrients were applied at equal rates to all pots, varying only in the amount of applied Si. Therefore, an influence of the soil type was only detected on the 
Table 2. Quantities of calcium and magnesium provided by silicate, lime and magnesium used in the experiments

\begin{tabular}{|c|c|c|c|c|c|c|c|}
\hline \multirow{2}{*}{$\mathbf{S i}$} & \multicolumn{2}{|c|}{ Silicate } & \multicolumn{2}{|c|}{ Lime } & \multirow{2}{*}{$\begin{array}{c}\mathrm{MgCl}_{2} \\
\mathrm{Mg}\end{array}$} & \multicolumn{2}{|c|}{ Total } \\
\hline & $\mathbf{C a}$ & Mg & $\mathbf{C a}$ & Mg & & $\mathbf{C a}$ & Mg \\
\hline 0 & 0.0 & 0.0 & 1343.4 & 376.0 & 0.0 & 1343.4 & 376.0 \\
\hline 185 & 447.5 & 97.0 & 895.6 & 250.7 & 28.3 & 1343.4 & 376.0 \\
\hline 370 & 895.6 & 194.0 & 447.8 & 125.3 & 56.6 & 1343.4 & 376.0 \\
\hline 555 & 1343.4 & 291.1 & 0.0 & 0.0 & 89.4 & 1343.4 & 376.0 \\
\hline
\end{tabular}

Table 3. Probability level of significance of the $F$ test for the analysis of variance of chemical characteristics of the Quartzipsamment (Q), Rhodic Hapludox (RH) and Rhodic Acrudox (RA) due to silicon application after harvesting of plant cane and two ratoons

\begin{tabular}{|c|c|c|c|c|c|c|c|c|c|c|}
\hline Cause of variation & $\mathrm{pH}\left(\mathrm{CaCl}_{2}\right)$ & $\mathbf{O M}$ & $\mathbf{P}^{(1)}$ & $\mathbf{K}$ & $\mathbf{C a}$ & Mg & CEC & $\mathbf{B S}^{(2)}$ & $\mathrm{Sia}^{(3)}$ & $\operatorname{Sic}^{(4)}$ \\
\hline & \multicolumn{10}{|c|}{ Plant cane } \\
\hline Soil (S) & $0.01^{*}$ & $0.01^{*}$ & $0.01^{*}$ & $0.01 *$ & $0.01^{*}$ & $0.01^{*}$ & $0.01 *$ & $0.01^{*}$ & $0.01 *$ & $0.01^{*}$ \\
\hline Rate (R) & $0.38^{\mathrm{NS}}$ & $0.24^{\mathrm{NS}}$ & $0.43^{\mathrm{NS}}$ & $0.74^{\mathrm{NS}}$ & $0.65^{\mathrm{NS}}$ & $0.62^{\mathrm{NS}}$ & $0.67^{\mathrm{NS}}$ & $0.78^{\mathrm{NS}}$ & $0.01^{*}$ & $0.01^{*}$ \\
\hline \multirow[t]{2}{*}{$\mathrm{S}^{*} \mathrm{R}$} & $0.95^{\mathrm{NS}}$ & $0.78^{\mathrm{NS}}$ & $0.92^{\mathrm{NS}}$ & $0.83^{\mathrm{NS}}$ & $0.95^{\mathrm{NS}}$ & $0.17^{\mathrm{NS}}$ & $0.99^{\mathrm{NS}}$ & $0.82^{\mathrm{NS}}$ & $0.01^{*}$ & $0.02^{*}$ \\
\hline & \multicolumn{10}{|c|}{ First ratoon } \\
\hline Soil (S) & $0.01^{*}$ & $0.01^{*}$ & $0.01^{*}$ & $0.01^{*}$ & $0.01^{*}$ & $0.01^{*}$ & $0.01^{*}$ & $0.01^{*}$ & $0.01 *$ & $0.01^{*}$ \\
\hline Rate $(\mathrm{R})$ & $0.91^{\mathrm{NS}}$ & $0.85^{\mathrm{NS}}$ & $0.21^{\mathrm{NS}}$ & $0.31^{\mathrm{NS}}$ & $0.30^{\mathrm{NS}}$ & $0.51^{\mathrm{NS}}$ & $0.32^{\mathrm{NS}}$ & $0.32^{\mathrm{NS}}$ & $0.01 *$ & $0.03^{*}$ \\
\hline \multirow[t]{2}{*}{$\mathrm{S} * \mathrm{R}$} & $0.28^{\mathrm{NS}}$ & $0.45^{\mathrm{NS}}$ & $0.23^{\mathrm{NS}}$ & $0.56^{\mathrm{NS}}$ & $0.08^{\mathrm{NS}}$ & $0.62^{\mathrm{NS}}$ & $0.73^{\mathrm{NS}}$ & $0.52^{\mathrm{NS}}$ & $0.01^{*}$ & $0.04^{*}$ \\
\hline & \multicolumn{10}{|c|}{ Second ratoon } \\
\hline Soil (S) & $0.01^{*}$ & $0.01^{*}$ & $0.02^{*}$ & $0.02^{*}$ & $0.01^{*}$ & $0.02^{*}$ & $0.02^{*}$ & $0.02^{*}$ & $0.02 *$ & $0.02^{*}$ \\
\hline Rate (R) & $0.01^{*}$ & $0.24^{\mathrm{NS}}$ & $0.14^{\mathrm{NS}}$ & $0.10^{\mathrm{NS}}$ & $0.01^{*}$ & $0.19^{\mathrm{NS}}$ & $0.10^{\mathrm{NS}}$ & $0.11^{\mathrm{NS}}$ & $0.03 *$ & $0.02^{*}$ \\
\hline $\mathrm{S}^{*} \mathrm{R}$ & $0.34^{\mathrm{NS}}$ & $0.10^{\mathrm{NS}}$ & $0.24^{\mathrm{NS}}$ & $0.10^{\mathrm{NS}}$ & $0.06^{\mathrm{NS}}$ & $0.49^{\mathrm{NS}}$ & $0.02^{\mathrm{NS}}$ & $0.23^{\mathrm{NS}}$ & $0.04^{*}$ & $0.03^{*}$ \\
\hline
\end{tabular}

(1) P: extracted by anionic resin; ${ }^{(2)}$ Base saturation; ${ }^{(3)}$ Soluble $\mathrm{Si}$ in $0.5 \mathrm{~mol} \mathrm{~L}{ }^{-1}$ acetic acid; ${ }^{(4)}$ Soluble $\mathrm{Si}$ in $0.01 \mathrm{~mol} \mathrm{~L}^{-1} \mathrm{CaCl}_{2}$; ${ }^{*}$ and NS significant at $5 \%$ and non-significant, respectively by the $\mathrm{F}$ test.

Table 4. Average chemical characteristics of the Quartzipsamment (Q), Rhodic Hapludox (RH) and Rhodic Acrudox (RA) soils due to silicon application after harvesting plant cane and two ratoon crops

\begin{tabular}{|c|c|c|c|c|c|c|c|c|c|c|}
\hline Cause of variation & $\mathrm{pH}\left(\mathrm{CaCl}_{2}\right)$ & $\mathbf{O M}$ & $\mathbf{P}^{(1)}$ & $\mathbf{K}$ & $\mathbf{C a}$ & Mg & CEC & $\mathbf{B S}^{(2)}$ & $\mathrm{Sia}^{(3)}$ & $\operatorname{Sic}^{(4)}$ \\
\hline & & $\mathrm{g} \mathrm{kg}^{-1}$ & $\mathrm{mg} \mathrm{dm}{ }^{-3}$ & \multicolumn{4}{|c|}{$-\mathrm{mmol}_{\mathrm{c}} \mathrm{dm}^{-3}-$} & $\%$ & \multicolumn{2}{|c|}{$\longrightarrow \mathrm{mg} \mathrm{kg}^{-1}$} \\
\hline & \multicolumn{10}{|c|}{ Plant cane } \\
\hline Q & $7.1 \mathrm{a}$ & $10.3 \mathrm{c}$ & $12.6 \mathrm{a}$ & $0.2 \mathrm{c}$ & $34.5 \mathrm{~b}$ & $6.6 \mathrm{c}$ & $47.7 \mathrm{c}$ & $86.1 \mathrm{a}$ & $30.1 \mathrm{c}$ & $3.9 \mathrm{c}$ \\
\hline $\mathrm{RH}$ & $6.8 \mathrm{~b}$ & $24.1 \mathrm{~b}$ & $16.1 \mathrm{a}$ & $0.6 \mathrm{~b}$ & $57.1 \mathrm{a}$ & $17.1 \mathrm{~b}$ & $85.4 \mathrm{~b}$ & $87.3 \mathrm{a}$ & $44.7 \mathrm{~b}$ & $8.7 \mathrm{~b}$ \\
\hline $\mathrm{RA}$ & $5.6 \mathrm{c}$ & $31.6 \mathrm{a}$ & $5.5 \mathrm{~b}$ & $1.8 \mathrm{a}$ & $54.9 \mathrm{a}$ & $18.6 \mathrm{a}$ & $103.1 \mathrm{a}$ & $73.0 \mathrm{~b}$ & $57.9 \mathrm{a}$ & $20.8 \mathrm{a}$ \\
\hline \multirow[t]{2}{*}{$\mathrm{LSD}^{(5)}$} & 0.2 & 1.1 & 5.6 & 0.1 & 5.6 & 1.4 & 5.8 & 2.8 & 6.8 & 0.8 \\
\hline & \multicolumn{10}{|c|}{ First ratoon } \\
\hline $\mathrm{Q}$ & $5.9 \mathrm{a}$ & $8.2 \mathrm{c}$ & $7.7 \mathrm{~b}$ & $0.3 \mathrm{c}$ & $11.81 \mathrm{~b}$ & $5.02 \mathrm{c}$ & $26.7 \mathrm{c}$ & $69.9 \mathrm{~b}$ & $5.48 \mathrm{c}$ & $0.76 \mathrm{a}$ \\
\hline $\mathrm{RH}$ & $5.6 \mathrm{a}$ & $20.9 \mathrm{~b}$ & $13.9 \mathrm{a}$ & $0.5 \mathrm{~b}$ & $36.50 \mathrm{a}$ & $11.69 \mathrm{~b}$ & $62.5 \mathrm{~b}$ & $79.1 \mathrm{a}$ & $8.22 \mathrm{~b}$ & $1.76 \mathrm{~b}$ \\
\hline $\mathrm{RA}$ & $5.2 \mathrm{~b}$ & $30.7 \mathrm{a}$ & $6.1 \mathrm{~b}$ & $1.4 \mathrm{a}$ & $38.62 \mathrm{a}$ & $17.81 \mathrm{a}$ & 89.9 a & $63.0 \mathrm{c}$ & $11.95 \mathrm{a}$ & $3.98 \mathrm{~b}$ \\
\hline \multirow[t]{2}{*}{$\mathrm{LSD}^{(5)}$} & 0.34 & 1.35 & $2.1 \mathrm{~b}$ & 0.17 & 3.32 & 3.24 & 6.28 & 5.07 & 1.50 & 0.71 \\
\hline & \multicolumn{10}{|c|}{ Second ratoon } \\
\hline $\mathrm{Q}$ & $4.2 \mathrm{~b}$ & $12.8 \mathrm{c}$ & $9.6 \mathrm{ab}$ & $0.7 \mathrm{~b}$ & $11.0 \mathrm{~b}$ & $1.1 \mathrm{c}$ & $27.6 \mathrm{c}$ & $10.9 \mathrm{~b}$ & $4.8 \mathrm{c}$ & $1.4 \mathrm{c}$ \\
\hline $\mathrm{RH}$ & $4.3 \mathrm{a}$ & $23.8 \mathrm{~b}$ & $14.8 \mathrm{a}$ & $1.5 \mathrm{~b}$ & $13.7 \mathrm{a}$ & $2.9 \mathrm{~b}$ & $75.7 \mathrm{~b}$ & $24.5 \mathrm{a}$ & $12.5 \mathrm{~b}$ & $4.8 \mathrm{~b}$ \\
\hline $\mathrm{RA}$ & $4.2 \mathrm{~b}$ & $30.4 \mathrm{a}$ & $7.7 \mathrm{~b}$ & $3.8 \mathrm{a}$ & $15.6 \mathrm{a}$ & $6.2 \mathrm{a}$ & $129.4 \mathrm{a}$ & $23.1 \mathrm{a}$ & $17.9 \mathrm{a}$ & $10.2 \mathrm{a}$ \\
\hline $\mathrm{LSD}^{(5)}$ & 0.13 & 3.20 & 6.13 & 0.47 & 2.76 & 0.74 & 17.11 & 6.99 & 2.23 & 0.65 \\
\hline
\end{tabular}


values of organic matter $(\mathrm{OM}), \mathrm{P}, \mathrm{K}, \mathrm{Mg}$, cation exchange capacity (CEC), and BS in all three crops (Table 3) due to the specific characteristics of the soils, particularly of the texture.

The $\mathrm{OM}$ values were highest in the RA, followed by RH and Q (Table 4), decreasing with increasing clay content for all three crops. This result is in agreement with the known superior capacity of RA, in which the levels of OM remain higher due to the formation of soil aggregates (Silva \& Mendonça, 2007). Similar results were obtained for $\mathrm{Ca}, \mathrm{Mg}$, and CEC (Table 4) after the harvest of all three crops. In contrast, the $\mathrm{P}$ levels in the plant cane, BS in the plant cane and first ratoon, and $\mathrm{pH}$ values in all three crops were lowest for the RA (Table 4). This was due to the higher buffering capacity of RA, explained by its highest clay content and the total contents of $\mathrm{Fe}$ and $\mathrm{Al}$ oxides (Table 1). The reduction in $\mathrm{pH}$ and $\mathrm{Ca}$ levels over the three crops in all soils could be explained by the sugarcane uptake.

It is known that silicate is useful to correct soil acidity and supply Ca as well (Alcarde \& Rodela, 2003). Thus, the same quantities of Ca were applied to all pots (Table 2) to avoid any influence on the $\mathrm{pH}$ and $\mathrm{Ca}$ contents when different silicate rates were applied, as was observed in the plant cane and the first ratoon crops (Table 3). However, the $\mathrm{Si}$ applications (x) increased $\mathrm{pH}$ and $\mathrm{Ca}$ (Table $3, \mathrm{pH}=$ $4.082+0.00005 \mathrm{x}, \mathrm{R}^{2}=0.87^{*}, \mathrm{p}<0.05 ; \mathrm{Ca}=7.806+$ $\left.0.0085 \mathrm{x}, \mathrm{R}^{2}=0.90^{*}, \mathrm{p}<0.05\right)$ after the second ratoon harvest. Considering that only lime was used as $\mathrm{Ca}$ and $\mathrm{Mg}$ source in the control treatment (Table 2), it is possible that the neutralizing action of lime was inferior to that of silicate because the base $\left(\mathrm{CO}_{3}^{-2}\right)$ was weaker $\left(\mathrm{kb} 1=2.2 \times 10^{-4}\right)$ than the silicate base $\left(\mathrm{SiO}_{3}{ }^{-2}\right.$, $\left.\mathrm{kb} 1=1.6 \times 10^{-3}\right)$. Thus, the release of $\mathrm{OH}^{-}$in the soil was slow (Alcarde \& Rodella, 2003; Ramos et al., 2006). The increase in $\mathrm{pH}$ observed after the second ratoon showed the capacity of silicate to correct acidity over time, which would be advantageous for this longduration crop, aside from supplying the plants with Si. Brassioli et al. (2009) found that liming increased the cane yield, similarly to silicate. However, after the third harvest, the yield increase induced by silicate was greater.

The soluble Si extracted by $0.5 \mathrm{~mol} \mathrm{~L}^{-1}$ acetic acid increased with increasing silicate rates and was different for each soil type in all three crops (Figure 1), except for the second ratoon crop on RA (Figure 1e). However, the soluble Si extracted by $0.01 \mathrm{~mol} \mathrm{~L}^{-1} \mathrm{CaCl}_{2}$ was influenced by silicate only in the plant-cane crop (Figure 1b), due to the lower extractability of $\mathrm{CaCl}_{2}$ than of acetic acid (Camargo et al., 2007b; Pereira et al., 2004). The low pH (1.0-2.0) of the acetic acid solution can also extract non-available $\mathrm{Si}$, as that provided by silicate applications (Pereira et al., 2007).

To evaluate the Si availability of both extractants, the Si levels (x) extracted in acetic acid or $\mathrm{CaCl}_{2}$ in all three soils were examined as a function of the $\mathrm{Si}$ uptake (y). The linear regression equations were significant $(\mathrm{p}<0.05, \mathrm{~F}$ test) for soluble Si extracted by acetic acid from soil sampled after the plant cane harvest (Quartzipsamment-Q, $\hat{y}=3.005+0.0162 \mathrm{x}$, $\mathrm{R}^{2}=0.83^{*}, \mathrm{p}<0.05$; Rhodic Hapludox-RH, $\hat{\mathrm{y}}=0.76$ $+0.0761 \mathrm{x}, \mathrm{R}^{2}=0.83^{*}, \mathrm{p}<0.05$; Rhodic Acrudox-RA, $\left.\hat{\mathrm{y}}=1.517+0.0339 \mathrm{x}, \mathrm{R}^{2}=0.89^{*}, \mathrm{p}<0.05\right)$, the first ratoon $\left(\mathrm{RH}, \hat{\mathrm{y}}=4.248+0.659 \mathrm{x}, \mathrm{R}^{2}=0.87^{*}, \mathrm{p}<0.05\right.$; $\left.\mathrm{RA}, \hat{\mathrm{y}}=3.451+0.393 \mathrm{x}, \mathrm{R}^{2}=0.54^{*}, \mathrm{p}<0.05\right)$ and the second ratoon $\left(\mathrm{RH}, \hat{\mathrm{y}}=4.019+1.076 \mathrm{x}, \mathrm{R}^{2}=0.84^{*}\right.$, $\mathrm{p}<0.05$ ) as well as for silicon extracted by $\mathrm{CaCl}_{2}$ from plant cane (Quartzipsamment- $\mathrm{Q}, \hat{\mathrm{y}}=3.005+0.0162$ $\mathrm{x}, \mathrm{R}^{2}=0.83^{*}, \mathrm{p}<0.05$; Rhodic Hapludox-RH, $\hat{\mathrm{y}}=0.76$ $+0.0761 \mathrm{x}, \mathrm{R}^{2}=0.83^{*}, \mathrm{p}<0.05$; Rhodic Acrudox-RA, $\left.\hat{\mathrm{y}}=1.517+0.0339 \mathrm{x}, \mathrm{R}^{2}=0.89^{*}, \mathrm{p}<0.05\right)$, the first ratoon $\left(\mathrm{RH}, \hat{\mathrm{y}}=4.248+0.659 \mathrm{x}, \mathrm{R}^{2}=0.87^{*}, \mathrm{p}<0.05\right.$; $\left.R A, \hat{y}=3.451+0.393 x, R^{2}=0.54^{*}, p<0.05\right)$ and the second ratoon $\left(\mathrm{RH}, \hat{\mathrm{y}}=4.019+1.076 \mathrm{x}, \mathrm{R}^{2}=0.84^{*}\right.$, $\mathrm{p}<0.05)$. The determination coefficient $\left(\mathrm{R}^{2}\right)$ of the extractor acetic acid was the highest, resulting in a more precise determination of the Si supply in the long term, while $\mathrm{CaCl}_{2}$ extracted lower amounts, consisting only of the readily available silicon (Berthelsen et al., 1999).

For both extractants, the silicon content was higher in soils with higher clay content, in agreement with other studies (Raij \& Camargo, 1973; Freitas et al., 1977; Meyer \& Keeping, 2001; Camargo et al., 2007a). The $\mathrm{Q}$ soil showed the highest increase in soluble $\mathrm{Si}$ concentrations, followed by $\mathrm{RH}$ and $\mathrm{RA}$, due to the low clay contents (Figure 1). In addition, there was a pronounced reduction in soluble Si detected by both extractants after harvest, even in the RA (Figure 1), which had a higher initial Si content (Table 1). Berthelsen et al. (1999) also found a decrease in silicon levels after sugarcane cultivation. These authors reported superior Si contents in rainforest $(13.1 \mathrm{mg}$ $\mathrm{kg}^{-1} \mathrm{Si}$ extracted by $0.01 \mathrm{~mol} \mathrm{~L}^{-1} \mathrm{CaCl}_{2} ; 28 \mathrm{mg} \mathrm{kg}^{-1}$ $\mathrm{Si}-0.5 \mathrm{~mol} \mathrm{\textrm {L } ^ { - 1 }}$ acetic acid) compared with sugarcane $\left(5.3 \mathrm{mg} \mathrm{kg}^{-1}\right.$ extracted by $0.01 \mathrm{~mol} \mathrm{~L}^{-1}$ $\mathrm{CaCl}_{2} ; 12.8 \mathrm{mg} \mathrm{kg}^{-1} \mathrm{Si}-0.5 \mathrm{~mol} \mathrm{~L}^{-1}$ acetic acid) growing on the same soil. Although these authors suggested that $\mathrm{Si}$ uptake could decrease the soluble Si available in the soil over successive crops, this could also be the result of leaching and oxide sorption.

Silicon uptake by sugarcane was influenced by the treatments, but there was no interaction between the soils and silicon rates (Table 5). There was a linear increase in the Si uptake according to the rate of silicate application when averaged across the three soils for all three crops. The reason may be that the experiments were conducted in pots, which may have limited the root growth and improved the recovery index in successive crops. In contrast to these data, Anderson et al. (1991) observed a reduction in Si levels in soils after the harvest of successive ratoons of sugarcane under field conditions. The superior Si uptake observed in the ratoon crops can be explained by the more extensive root system than of plant cane, improving nutrient extraction. 
The Si uptake was highest in RA, when averaged across Si rates in the plant cane and first ratoon crops (Table 6), in agreement with the highest soluble $\mathrm{Si}$ concentrations (Figure 1). However, no difference was observed between soils in the second ratoon for $\mathrm{Si}$ concentrations (Table 3), due to the lower soluble $\mathrm{Si}$ contents than in the previous crops (Figure 1). These results confirm that Si fertilization could be an important tool for nutrient management to supply the soil for the high demand of sugarcane of this element, as previously shown in other studies (Samuels, 1969; Ross et al., 1974; Berthelsen et al., 1999).

The recovery index of applied silicon (RI) by plant cane was low (Table 7), despite the high concentrations of soluble $\mathrm{Si}$ in both extractants (Figure 1). The mean $\mathrm{RI}$ in plant cane was $2.5,4.5$ and $5.7 \%$ for $\mathrm{Q}, \mathrm{RH}$ and $\mathrm{RA}$, respectively. In the first ratoon crop, the values were $2.5,3.7$ and $6.2 \%$, respectively, and in the second ratoon, 10.5, 13.1 and $20.5 \%$, respectively. After the three sugarcane crops, the RI varied between 16.8
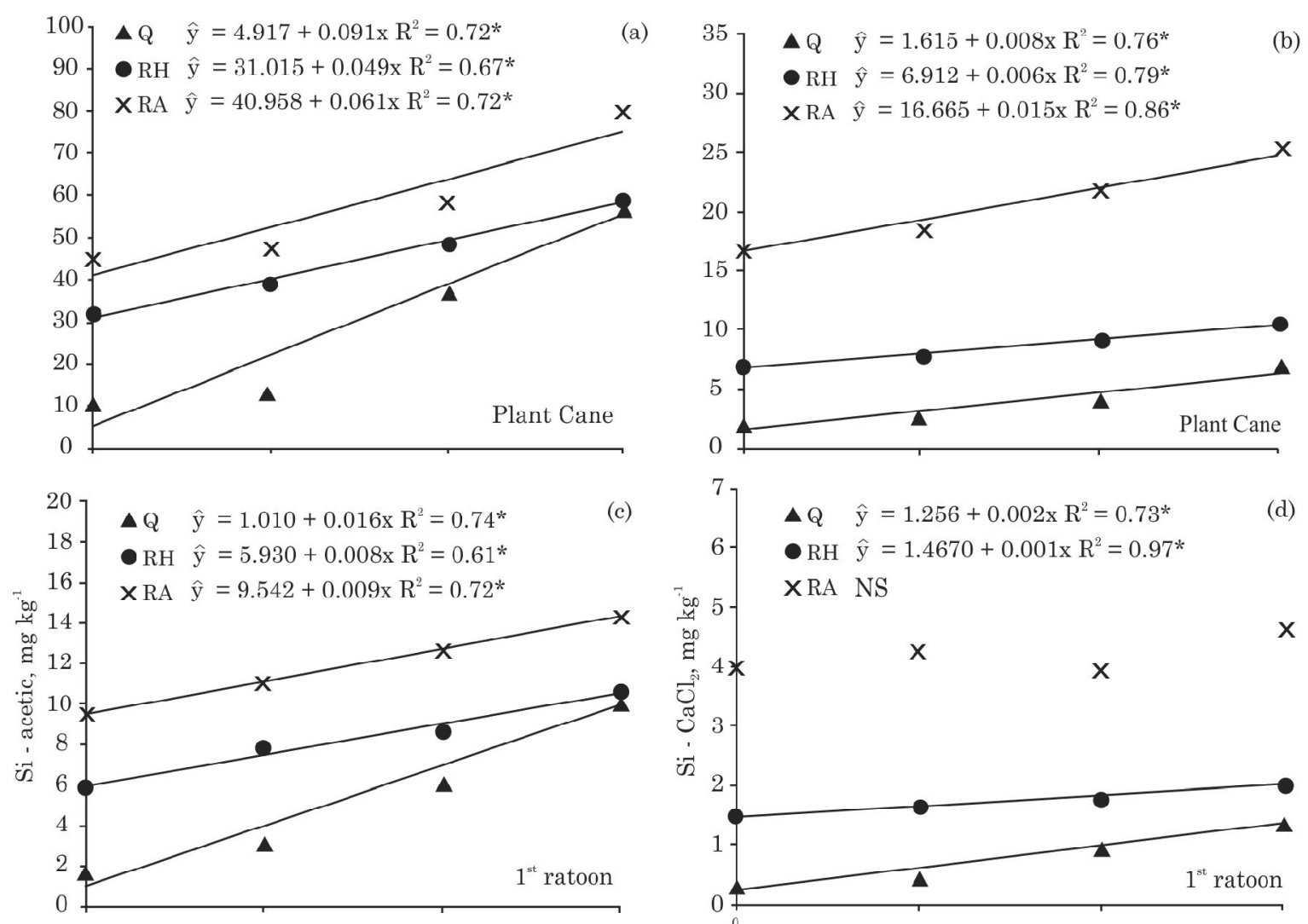

(b)
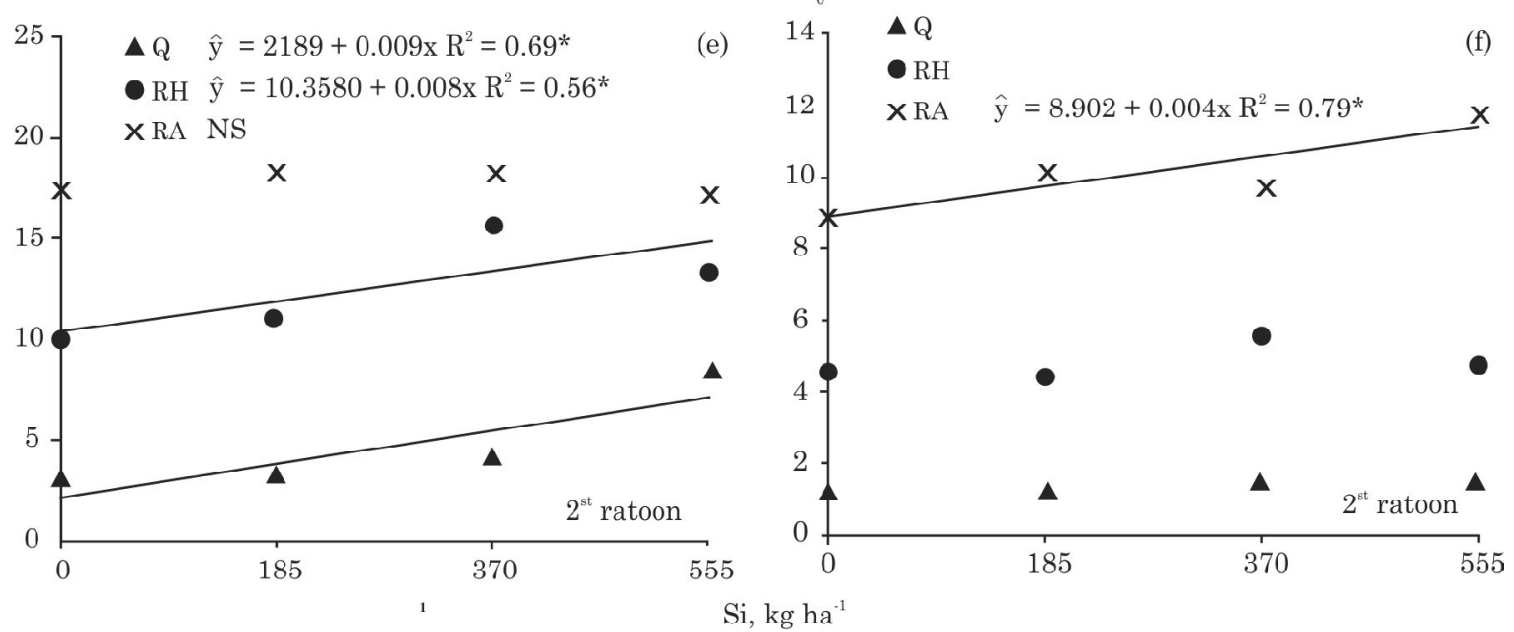

Figure 1. Soluble silicon in $0.5 \mathrm{~mol} \mathrm{~L}^{-1}$ acetic acid (a, c, e) and $0.01 \mathrm{~mol} \mathrm{~L}^{-1} \mathrm{CaCl}_{2}(\mathrm{~b}, \mathrm{~d}$, f) as a function of the $\mathrm{Si}$ application rate for Quartzipsamment (Q, $\Delta)$, Rhodic Hapludox (RH, ๑) and Rhodic Acrudox (RA, X) after plant cane, first ratoon and second ratoon. 
Table 5. Probability level of significance of the $\mathrm{F}$ test for the ANOVA results of dry matter and silicon (Si) uptake values by the aerial part of plant cane in Quartzipsamment (Q), Rhodic Hapludox (RH) and Rhodic Acrudox (RA) soils due to silicon application after the harvest of plant cane and two ratoon crops

\begin{tabular}{|c|c|c|c|c|c|c|}
\hline \multirow{2}{*}{ Cause of variation } & \multicolumn{3}{|c|}{ Si uptake } & \multicolumn{3}{|c|}{ Dry matter } \\
\hline & Plant cane & First ratoon & Second ratoon & Plant cane & First ratoon & Second ratoon \\
\hline Soil (S) & $0.01^{*}$ & $0.02 *$ & $0.05^{\mathrm{NS}}$ & $0.01^{*}$ & $0.01^{*}$ & $0.09^{\mathrm{NS}}$ \\
\hline Rate $(\mathrm{R})$ & $0.01^{*}$ & $0.01^{*}$ & $0.24^{\mathrm{NS}}$ & $0.30^{\mathrm{NS}}$ & $0.80^{\mathrm{NS}}$ & $0.06^{\mathrm{NS}}$ \\
\hline $\mathrm{S} * \mathrm{R}$ & $0.01^{*}$ & $0.42^{\mathrm{NS}}$ & $0.96^{\mathrm{NS}}$ & $0.49^{\mathrm{NS}}$ & $0.78^{\mathrm{NS}}$ & $0.65^{\mathrm{NS}}$ \\
\hline
\end{tabular}

* and ${ }^{\mathrm{NS}}$ significant at $5 \%$ and non significant, respectively, by the $\mathrm{F}$ test.

Table 6. Dry matter and silicon (Si) uptake values averaged across Si treatment by the aerial part of the plant cane of the Quartzipsamment (Q), Rhodic Hapludox (RH) and Rhodic Acrudox (RA) due to silicon application after harvesting plant cane, and two ratoon crops

\begin{tabular}{|c|c|c|c|c|c|c|}
\hline \multirow{2}{*}{ Cause of variation } & \multicolumn{3}{|c|}{ Si uptake } & \multicolumn{3}{|c|}{ Dry matter } \\
\hline & Plant cane & First ratoon & Second ratoon & Plant cane & First ratoon & Second ratoon \\
\hline $\mathrm{Q}$ & $3.9 \mathrm{~b}$ & $4.9 \mathrm{c}$ & $6.7 \mathrm{a}$ & $760.4 \mathrm{~b}$ & $930.9 \mathrm{~b}$ & $1423.9 \mathrm{~b}$ \\
\hline $\mathrm{RH}$ & $4.7 \mathrm{a}$ & $7.0 \mathrm{a}$ & $8.6 \mathrm{a}$ & 916.6 a & $959.2 \mathrm{~b}$ & $1602.8 \mathrm{a}$ \\
\hline $\mathrm{RA}$ & $4.0 \mathrm{~b}$ & $6.1 \mathrm{~b}$ & $9.2 \mathrm{a}$ & 915.9 a & 1170.6 a & $1524.9 \mathrm{ab}$ \\
\hline $\operatorname{LSD}^{(1)}$ & 0.5 & 0.8 & 2.8 & 101.1 & 120.7 & 174.9 \\
\hline
\end{tabular}

(1) Least Significant Difference (LSD): means followed by the same letter in the column in each harvest did not differ by Tukey's test $(\mathrm{p}<0.05)$.

Table 7. Silicon recovery from the silicate application calculated based on the Si uptake by the aerial part of sugarcane plants

\begin{tabular}{|c|c|c|c|c|c|c|c|c|c|c|c|c|}
\hline \multirow{2}{*}{ Si applied ${ }^{(1)}$} & \multicolumn{3}{|c|}{ Plant cane } & \multicolumn{3}{|c|}{ First ratoon } & \multicolumn{3}{|c|}{ Second ratoon } & \multicolumn{3}{|c|}{ Total } \\
\hline & Uptake & $\operatorname{SiFF}^{(2)}$ & $\mathbf{R} \mathbf{I}^{(3)}$ & Uptake & $\mathrm{SiFF}$ & RI & Uptake & SiFF & IR & Uptake & $\mathrm{SiFF}$ & RI \\
\hline \multirow[t]{2}{*}{ g/pot } & \multicolumn{2}{|c|}{ g/pot } & $\%$ & \multirow[t]{2}{*}{$-\mathrm{g} / \mathrm{pot}$} & - & \multirow{2}{*}{$\begin{array}{l}\% \\
\text { zipsar }\end{array}$} & \multicolumn{2}{|c|}{$\mathrm{g} / \mathrm{pot}$} & \multirow[t]{2}{*}{$\%$} & \multicolumn{2}{|c|}{$\mathrm{g} / \mathrm{pot}-$} & \multirow[t]{2}{*}{$\%$} \\
\hline & & & & & Que & & nment (Q) & & & & & \\
\hline 0.0 & 3.5 & 0.0 & - & 4.4 & 0.0 & - & 5.1 & 0.0 & - & 12.9 & 0.0 & - \\
\hline 9.25 & 3.6 & 0.1 & 1.1 & 4.5 & 0.1 & 1.1 & 6.0 & 0.9 & 9.7 & 14.2 & 1.3 & 14.1 \\
\hline 18.50 & 3.9 & 0.4 & 2.2 & 4.8 & 0.4 & 2.2 & 6.5 & 1.4 & 7.6 & 15.3 & 2.4 & 13.0 \\
\hline \multirow[t]{2}{*}{27.75} & 4.7 & 1.2 & 4.3 & 5.7 & 1.3 & 4.3 & 9.0 & 3.9 & 14.1 & 19.4 & 6.5 & 23.4 \\
\hline & \multicolumn{12}{|c|}{ Rhodic Hapludox (RH) } \\
\hline 0.0 & 3.9 & 0.0 & - & 6.4 & 0.0 & - & 6.5 & 0.0 & - & 16.8 & 0.0 & \\
\hline 9.25 & 4.1 & 0.2 & 2.7 & 6.5 & 0.1 & 1.3 & 6.7 & 0.2 & 2.7 & 17.3 & 0.5 & 6.7 \\
\hline 18.50 & 4.1 & 0.2 & 1.1 & 6.9 & 0.5 & 2.9 & 10.1 & 3.6 & 20.6 & 21.4 & 4.6 & 26.3 \\
\hline \multirow[t]{2}{*}{27.75} & 6.6 & 2.7 & 9.8 & 8.3 & 1.9 & 6.9 & 10.9 & 4.4 & 16.0 & 25.8 & 9.0 & 32.7 \\
\hline & \multicolumn{12}{|c|}{ Rhodic Acrudox (RA) } \\
\hline 0.0 & 3.3 & 0.0 & - & 5.3 & 0.0 & - & 7.0 & 0.0 & - & 15.7 & 0.0 & - \\
\hline 9.25 & 3.8 & 0.5 & 6.7 & 5.6 & 0.3 & 4.0 & 8.4 & 1.4 & 18.7 & 17.8 & 2.1 & 28.0 \\
\hline 18.50 & 4.4 & 1.1 & 6.3 & 7.1 & 1.8 & 10.3 & 11.1 & 4.1 & 23.4 & 22.6 & 6.9 & 39.4 \\
\hline 27.75 & 4.4 & 1.1 & 4.0 & 6.5 & 1.2 & 4.4 & 10.4 & 3.3 & 19.4 & 21.3 & 5.6 & 20.4 \\
\hline
\end{tabular}

(1) Silicon rates $\left(185,370,555 \mathrm{~kg} \mathrm{ha}^{-1} \mathrm{Si}\right)$ corresponding to $9.25 ; 18.50$ and $27.75 \mathrm{~g} / \mathrm{pot} ;{ }^{(2)} \mathrm{SiFF}$ (Si uptake by sugarcane from silicate) $=$ Si uptake - Si uptake by control; ${ }^{(3)} \mathrm{RI}(\%)$ (Recovery Index) $=(\text { SiFF/Si applied })^{*} 100$. 
and $29.3 \%$. This RI increase observed over the three crops could be explained by the differences in dry matter and Si uptake (Table 6).

The RI of Si was the best in RA in all three crops (Table 7), in agreement with the highest soluble $\mathrm{Si}$ content in the extractants (Figure 1) and the best Si uptake in the plant cane and the first ratoon crops (Table 4). The highest clay content promoted the best reactivity of silicate, in agreement with Korndörfer et al. (1999). Although the clay content of the soil is important for the reactivity of the applied silicate, the recovery of Si by sugarcane is also influenced by the experimental conditions. In sugarcane grown in pots $(200 \mathrm{~L})$ with sandy-loam soil, Sousa et al. (2010) found a Si recovery index of $56.6,35.8$ and $25.8 \%$, after applications of 100,200 and $400 \mathrm{~kg} \mathrm{ha}^{-1} \mathrm{Si}$, respectively. However, Khalid et al. (1978) found lower values of the recovery index of $\mathrm{Si}(10 \%)$ after two crops (18 months) of sugarcane grown under field conditions in a clay soil with high oxide content.

Considering these results, it can be concluded that Si fertilizer can increase Si availability and uptake in sugarcane with residual effects, even in clay soils. Additionally, the Si recovery index over successive sugarcane crops is highest in clayey soils. After three sugarcane crops, the application of calcium magnesium silicate can induce an average Si uptake of 16.8 to $29.3 \%$ in the three soils.

\section{ACKNOWLEDGEMENT}

The authors are grateful to the State of São Paulo Research Foundation (FAPESP) for providing financial support and scholarships for this work.

\section{LITERATURE CITED}

ALCARDE, J.A. \& RODELLA, A.A. Qualidade e legislação de fertilizantes e corretivos. In: CURI, N.; MARQUES, J.J.; GUILHERME, L.R.G.; LIMA, J.M.; LOPES, A.S. \& ALVARES V., V.H., eds. Tópicos em Ciência do Solo. Viçosa, Sociedade Brasileira de Ciência do Solo, 2003. v. 3. p.291334.

ANDERSON, D.L. Soil and leaf nutrient interactions following application of calcium silicate slag to sugarcane. Fert. Res., 30:9-18, 1991.

AYRES, A.S. Calcium silicate slag as a growth stimulant for sugarcane on low-silicon soils. Soil Sci., 101:216-227, 1966.

BERTHELSEN, S.; HURNEY, A.; KINGSTON, G.; RUDD, A.; GARSIDE, A.L. \& NOBLE, A. Plant cane responses to silicated products in the Mossman, Innisfail and Bundaberg districts. Proc. Aust. Sugar Cane Technol., 23:297-303, 2001.
BERTHELSEN, S.; NOBLE, A.D. \& GARSIDE, A.L. An Assessment of soil and plant silicon levels in North Queensland. Proc. Aust. Sugar Cane Technol., 21:92-100, 1999.

BERTHELSEN, S.; NOBLE, A.; KINGSTON, G.; HURNEY, A. \& RUDD, A. Effect of Ca-silicate amendments on soil chemical properties under a sugarcane cropping system. In: SILICON IN AGRICULTURE CONFERENCE, 2., 2002. Proceedings... Tsuruoka, Japan, Japanese Society of Soil Science and Plant Nutrition, 2002. p.57.

BERTHELSEN, S.; NOBLE, R.; NOBLE, A. \& COVENTRY, R. Impact of silicon on sugarcane productivity. Proc. Aust. Sugar Cane Technol., 20:256, 1998.

BRASSIOLI, F.B.; PRADO, R.M. \& FERNANDES, F.M. Avaliação agronômica da escória de siderurgia na canade-açúcar durante cinco ciclos de produção. Bragantia, 68:381-387, 2009.

CAMARGO, M.S.; KORNDÖRFER, G.H. \& PEREIRA, H.S. Solubilidade do silício em solos: influência do calcário e ácido silícico aplicados. Bragantia, 66:637-647, 2007a.

CAMARGO, M.S.; KORNDÖRFER, G.H.; PEREIRA, H.S.; QUEIROZ, A.A. \& REIS, C.B. Soil reaction and absorption of silicon by rice. Sci. Agric., 64:176-180, 2007b.

COMPANHIA NACIONAL DE ABASTECIEMNTO - CONAB. Acompanhamento de safra brasileira: cana-de-açúcar, terceiro levantamento, janeiro/2011. Brasília, Conab, 2012. Disponível em: <http://www.conab.gov.br/ O l a l a C M S/ u p l o a d s/a r qui vos / 12_08_09_15_07_05_boletim_cana_portugues__agosto_2012_2o_lev.pdf>.

ELAWAD, S.H.; STREET, J.J. \& GASCHO, G.J. Response of sugarcane to silicate source ad rate. I. Growth and yield. Agron. J., 74:481-484, 1982.

ELLIOT, C.L. \& SNYDER, G.H. Autoclave-induced digestion for the colorimetric determination of silicon in rice straw. J. Agric. Food Chem., 39:1118-1119, 1991.

FOX, R.L.; LEVA, J.A.; YOUNG, O.P.; PLUNCKNETT, U.L. \& HERMAW, G.D. Soil and plant silicon and silicate response by sugarcane. Soil Sci. Soc. Am. Proc., 31:775779, 1967.

FREITAS, L.C.; COSTA FILHO, J.F.; ALOISI, R.R. \& MELO, W.J. Contribuição ao estudo da sílica solúvel em alguns perfis de solos. Científica, 5:296-305, 1977.

KHALID, R.A.; SILVA, J.A. \& FOX, R.L. Residual effects of calcium silicate in tropical soils: I. Fate of applied silicon during five years cropping. Soil Sci. Soc. Am. J., 42:89-97, 1978.

KORNDÖRFER, G.H.; COELHO, N.M.; SNYDER, G.H. \& MIZUTANI, C.T. Avaliação de métodos de extração de silício para solos cultivados com arroz de sequeiro. R. Bras. Ci. Solo, 23:101-106, 1999.

KORNDÖRFER, G.H.; PEREIRA, H.S. \& CAMARGO, M.S. Silicatos de cálcio e magnésio. Uberlândia, MG, Universidade Federal de Uberlândia, 2002a. 23p. 
KORNDÖRFER, G.H.; PEREIRA, H.S. \& CAMARGO, M.S. Papel do silício na produção de cana-de-açúcar. Stab, 21:69, 2002b.

LANDELL, M.G.A.; CAMPANA, M.P.; FIGUEIREDO, P.; ZIMBACK, L.; SILVA, M.A. \& PRADO, H. Novas variedades de cana-de-açúcar. Campinas, Instituto Agronômico de Campinas, 1997. 28p. (Boletim Técnico, 169)

MEYER, J.H. \& KEEPING, M.G. Past, present and future research of the role silicon for sugarcane in southern Africa. In: DATNOFF. L.E.; SNYDER, G.H. \& KORNDÖRFER, G.H., eds. Silicon in Agriculture. Amsterdam, Elsevier, 2001. p.257-274.

PEREIRA, H. S.; BARBOSA, N. C.; CARNEIRO, M. A. C. \& KORNDÖRFER, G.H. Avaliação de fontes e extratores de silício no solo. Pesq. Agropec. Bras., 42:239-247, 2007.

PEREIRA, H.S.; KORNDÖRFER, G.H.; VIDAL, A.A. \& CAMARGO, M.S. Silicon sources for rice crop. Sci. Agric., 61:522-528, 2004.

RAMOS, L.A.; KORNDÖRFER, G.H. \& NOLLA. A. Acúmulo de silício em plantas de arroz do ecossistema de várzea submetido à aplicação de diferentes fontes. Bragantia, 67:751-757, 2008.

RAIJ, B.van \& CAMARGO, O.A. Sílica solúvel em solos. Bragantia, 32:223-231, 1973.
RAIJ, B.van; CANTARELLA, H.; QUAGGIO, J.A. \& FURLANI, A.M.C. Recomendações de adubação e calagem para o estado de São Paulo. Campinas: Instituto Agronômico/ Fundação IAC, 1997. 285p.

ROSS, L.; NABABSING, P. \& CHEONG, W.Y. Residual effect of calcium silicate applied to sugarcane soils. Proc. Cong. Soc. Sugar Cane Technol., 15:539-542, 1974.

SAMUELS, G. Silicon and sugar. Sugar Azucar, 66:25-29, 1969.

SILVA, I.R. \& MENDONÇA, E.S. Matéria orgânica do solo. In: NOVAIS, R.F.; ALVAREZ V., V.H.; BARROS, N.F.; FONTES, R.L.F.; CANTARUTTI, R.B. \& NEVES, J.C.L., eds. Fertilidade do Solo. Viçosa, Sociedade brasileira de Ciência do Solo, 2007. p.275-374.

SILVEIRA, E.J.; PENATTI, C.; KORNDÖRFER, G.H. \& CAMARGO, M.S. Silicato de cálcio e calcário na produção e qualidade da cana-de-açúcar-Usina Catanduva. In: CONGRESSO BRASILEIRO DE CIÊNCIA DO SOLO. 29., 2003. Anais... Ribeirão Preto, UNESP, 2003. CD ROM

SOUSA, R.T.X.; KORNDÖRFER, G.H. \& WANGEN, D.R.B. Aproveitamento de silício proveniente de escória siderúrgica por cultivares de cana-de-açúcar. Bragantia, 69:669-676, 2010.

VETTORI, L. Método de análise de solo. Equipe de Pedologia e Fertilidade do Solo, Ministério da Agricultura. 1969. 34p. (Boletim Técnico, 7) 